\title{
IS A NON-METAPHYSICAL RELIGIOUS THOUGHT POSSIBLE? \\ - Possibility of Religious Thought within the Scope of Heidegger's Onto-theology Criticism -
}

\author{
Kasım Küçükalp \\ Uludağ University, Bursa-Turkey
}

\begin{abstract}
This article aims to treat the uniqueness of religious thought as a subject of reflection by reference to Martin Heidegger's philosophy since his views incorporate such a deeply rooted analysis. In pursuing the subject the article inquiries into the possibility of a non-metaphysical religious mode of thought in considering Heidegger's critique of traditional Western metaphysics, his assessments on the onto-theological and humanistic character of metaphysics, and his evaluations on the meaning of true thinking pursuant to the mode of thought he calls ontological. With regard to our assessments of religious thought, we take Heidegger's onto-theological criticisms as a point of departure. However, considering his philosophy and manner of thinking, we try to reveal what kind of possibilities the Heideggerian view can provide us in terms of religious thinking. Therefore, it is important that our assessments of religious thought not be interpreted as identical to Heidegger's philosophy but rather as ideas that he might have potentially incorporated into his own philosophy.
\end{abstract}

Key Words: Religious thought, Heidegger, onto-theology, metaphysical thinking, religion, calculative thinking, meditative thinking 


\section{Introduction}

Since the beginnings of modern thought, numerous philosophers and scientists have critiqued metaphysics and the notions of metaphysical truth in various forms and conceptualizations. Modern thought often embraces a scientific and rational worldview that goes against many conventional philosophies and concepts of truth, including religious and mythological thinking. On the one hand, religious morals and laws can be incorporated into an entirely rational worldview within the scope of "nature" identified with "ratio." On the other hand, in the wake of modern scientific and Cartesian influences, a subject who is isolated from all historicity, contingency, desire, life and the entire realm of being is construed to be the master of universe. According to this perspective, which reached full maturity during the Enlightenment, a man who claims to have attained intellectual maturity by displaying the "courage to make use of your own mind" needs to reference nothing except science and his own intellect. Such an attitude evidently made everything, including God, man, things, the universe and being, an epistemic object of human thought. Therefore, it has become almost impossible to establish a truly ontological relationship with the abovementioned realms of being.

The most apparent influence of this view on religious thought involved substituting the experience of religion with a scientific worldview, imposing a conceptual and rational framework that was designed by humans onto religion, and encouraging an individual pietism that was isolated from all institutionalization and consistent with the atomistic concept of the subject. Limiting the relationship between the individual and God, therefore, upheld a religious way of thinking that had been degraded to a mere function as a result of these issues. In our opinion, when it comes to modes of thought particularly religious thought - a deeply rooted inquiry is generally needed in order to comprehend such transformations. In the present study, which aims to treat the uniqueness of religious thought as a subject of reflection, we have chosen the philosophy of Martin Heidegger, since his views incorporate such a deeply rooted analysis. Obviously, our intention is not to associate Heidegger, who spent his entire lifetime addressing the "meaning of Being," with religious thinking or to introduce him as a kind of religious or mystic figure. Our objective is rather to investigate the possibility of a non- 
metaphysical religious mode of thought in considering Heidegger's critique of traditional Western metaphysics (which he addresses in order to obtain an authentic experience of Being), his assessments on the onto-theological and humanistic character of metaphysics, as well as his evaluations on the meaning of true thinking pursuant to the mode of thought he calls ontological. At this point, it is worth noting that with regard to our assessments of religious thought, we take Heidegger's onto-theological criticisms as a point of departure. Nevertheless, considering his philosophy and manner of thinking, we try to reveal what kind of possibilities the Heideggerian view can provide us in terms of religious thinking. Therefore, it is important that our assessments of religious thought not be interpreted as identical to Heidegger's philosophy but rather as ideas that he might have potentially incorporated into his own philosophy.

In order to understand Heidegger's criticism of onto-theological thought, we must first understand how he evaluates and criticizes traditional Western metaphysics, which in a sense he identifies with the oblivion of Being. According to Heidegger, Western metaphysical thinking involves forgetting the ontological difference between Being and beings. All beings find their meaning during historical periods of exposure in which the Being that is not a being is reduced to a mere being. Identifying Socratic rationalism as the source of such an approach, Heidegger affirms that metaphysical thought paved the way for the destruction of the truth - and therefore the meaning - of Being, since it is inclined towards reducing everything to the rational, pursuant to its humanistic character.

According to Heidegger, throughout the Western metaphysical tradition, the meaning of Being goes unconsidered because it is instead designed as being, whereas the possibility of a true reflection towards Being depends on the possibility of a non-metaphysical reflection found in pre-Socratic thinkers. We think that the interpretation of such an approach in religious thought can be possible only through a method of thinking that enables a transition "from a conception of God that is made an object of imagination to a conception in which God is considered as one to shape imagination." This method of thinking means that the thing which is made the object of reflection (such as Being, God, man, etc.) should be reflected in terms of its Being. In other words, "ontologically" as Heidegger puts it, it necessitates the true experience of its Being - and therefore, an es- 
sential change in terms of its manner of thinking - rather than being designed in certain epistemic practices. Without a doubt, this method of thinking requires reflecting on the meaning of a metaphysical thought that essentially possesses a calculative nature.

\section{Metaphysical Thinking in the Heideggerian Sense}

In general terms, metaphysics can be described as the search for an unchanging substance behind any change. When considered within the context of such a definition, the common issue of the Western metaphysical tradition has been establishing Being (Sein) as presence. ${ }^{1}$ This characteristic of the Western metaphysical tradition, which is criticized by Heidegger for reducing the Being to a being, involves searching for a constant and permanent source by means of binary oppositions. By reducing the Being to a being and defining it ahistorically, this definition defines the truth as something that can be obtained via certain epistemological tools.

In the Heideggerian view, "Metaphysics is inquiry beyond or over beings that aims to recover them as such and as a whole for our grasp." ${ }^{2}$ According to Heidegger, Western metaphysical thought, starting with Platonic philosophy, positions the Being outside of us as a being. By defining philosophy as striving for the Sophon, ${ }^{3}$ it has forgotten the true distinction between Being and beings. ${ }^{4}$ Therefore, it has grown away from reflecting on Being, and this fact reached its radical peak in terms of the complete oblivion of Being through modern technology, in which metaphysics is, in a sense, embodied.

1 John Sallis, "Heidegger/Derrida and Presence," The Journal of Philosophy 81/10 (1984: Eighty-First Annual Meeting American Philosophical Association, Eastern Division), 597.

2 Martin Heidegger, Metafizik Nedir? (translated into Turkish by Yusuf Örnek; Ankara: Türkiye Felsefe Kurumu, 1991), 38; cf. id., "What is Metaphysics?" (trans. David Farrell Krell), in his Pathmarks (ed. William McNeill; Cambridge: Cambridge University Press, 1998), 93.

3 Heidegger, Nedir Bu Felsefe? (translated into Turkish by Dürrin Tunç; Istanbul: Logos Yayinc1lik, 1990), 23; cf. id., What is Philosophy? (translated with an introduction by William Kluback and Jean T. Wilde; Albany: New College and University Press, 1956), 51.

4 Heidegger, "Letter on Humanism" (trans. Frank A. Capuzzi), in his Pathmarks, 246. 
According to Heidegger, for pre-Socratic thinkers, such as Heraclitus, the word philosophos meant to speak, like Logos, in harmony with sophon, and therefore, to correspond with logos. ${ }^{6}$ On the other hand, theoria meant to contemplate the truth beyond any utility. ${ }^{7}$ However, along with the conceptualization of philosophy as striving for sophon (due to metaphysics, for instance), Aristotle defines philosophy as the knowledge of first causes. The concept of theory experienced its greatest semantic shift in modern philosophy, as observation (Betrachtung) began to signify the entrapment of reality within the scope of certain epistemological setups. ${ }^{8}$ Beyond any doubt, the essentialist character of traditional Western metaphysics provides the underlying reason for a manner of thinking that determines the Being as such and reduces it to being by means of making Being an epistemic object rather than reflecting as it is. Pursuant to this essentialist character, philosophy prefers to establish a concept of truth that exists independently of life, existence and historicity by defining its object of reflection in terms of its essence and its most basic characteristics due to a rationalistic conception of being. In Heidegger's view, Aristotle constitutes the most apparent example of this determination since he clearly distinguishes essence from existence, and the philosophy as treated by Aristotle "is a kind of aptness which makes it possible to see being in respect to what it is in so far as it is being."

Because of this, Heidegger believes that metaphysical research comes across beings everywhere, but it can never find the Being that is not a being. Since Being is not an attribute present in being, it can neither be objectively designed nor embodied like being. Indeed, Being, which is completely different from all beings, is essentially

5 Sophon signifies that all beings are collected and present in Being. The Being is being; where "is" is transitive and refers to being collected. In other words, Being collects beings by existence, Being is collection. Heidegger, What is Philosophy? 46-48.

6 Heidegger, Nedir Bu Felsefe?, 21; cf. id., What is Philosophy?, 47.

7 Heidegger, "Bilim ve Düşünüm [Science and Reflection]," in his Bilim Üzerine İki Ders [Two Essays by Heidegger on Science] (translated into Turkish by Hakk1 Hünler; Istanbul: Paradigma Yayınları, 1998), 23.

$8 \quad$ Ibid., 27.

9 Heidegger, Nedir Bu Felsefe?, 27; cf. id., What is Philosophy?, 59. 
Non-being. ${ }^{10}$ Therefore, the ontological distinction between the Being and beings, which is crucial in the Heideggerian view, is forgotten within the scope of metaphysical thought since the Being is reduced to a being. The history of metaphysics corresponds with the history of forgetting this distinction. The comprehension of Being reduced to being as a fundamental cause and principle for everything involves adopting a perspective that perceives everything as identical and therefore indistinguishable. This perspective explains everything via the same logical principles that eliminate the difference between Being and beings within sameness. Nevertheless, according to Heidegger, the difference between beings reaches significance only with regard to the distinction between Being and beings. As a nonbeing, Being is diversely revealed in beings. However, to associate this entire process of revealing with a single logic means ruling out the difference, namely the ontological distinction, between the Being and beings within such a logic of identity.

From a Heideggerian perspective, the origin of this dominant manner of thinking in traditional Western metaphysics lies in its humanistic nature. There is a strict relationship between humanism, which bestows a privileged place to the human subject in epistemology and reduces everything to the intellect of the human subject, and metaphysical thought. The possibility of humanism is ensured through metaphysics granting a central and exclusionist role to man. ${ }^{11}$ In other words, metaphysics can subsist only if its humanistic nature, which reduces everything to the human subject in rationalistic terms, remains concealed. As Gianni Vattimo points out, the humanistic character within Western metaphysics is reflected in modern philosophy through the Cartesian cogito, which makes man the master of the universe by positioning him in the center of the universe. ${ }^{12}$ This perspective reached its peak with the Enlightenment. As many Enlightenment thinkers would agree, the Enlightenment principally addresses the salvation of man by maturing him in the sense of reason, and it

10 Heidegger, Metafizik Nedir?, 45-46.

11 Heidegger, "Letter on Humanism," 245.

12 Gianni Vattimo, Modernliğin Sonu: Postmodern Kültürde Nibilizm ve Hermenötik [The End of Modernity: Nibilism and Hermeneutics in Post-modern Culture] (translated into Turkish by Şehabettin Yalçın; Istanbul: İz Yayıncılık, 1999), 86. 
emphasizes that both religion and metaphysics* - along with progressive historicism and rational maturation - should be abandoned. ${ }^{13}$ Especially when considered in terms of modern epistemology, which asserts the right method as the prerequisite of obtaining true knowledge, humanism, which can in a sense be interpreted as leaving everything to the human subject's will, assigns a privileged place to the representative and the theorizing on the one hand, in the sense of prioritizing theory over reality. On the other hand, it detaches man from life and the entire Being, as a necessary consequence of detachment between theory and practice. ${ }^{14}$ In order to describe this manner, which Heidegger deems dominant in the entire tradition of Western metaphysics, he uses the expression "calculative thinking"** as separate from meditative thinking.

Pursuant to his general criticisms of metaphysics, Heidegger affirms that calculative thinking corresponds to philosophical and scientific thinking, and it can be considered an act of computing. In line with its epistemological and humanistic character, this manner of thinking treats its object of reflection in terms of its essence and main characteristics, making it an object of rational reflection. In one sense, this is nothing but the construction of a metaphysical, and thus fictional, being that is reduced to the intellect of the human subject via

* At this point, we have to say that metaphysics are not addressed in the same way by Enlightenment thought in the Heideggerian sense. In Enlightenment thought, metaphysics tends to describe and exclude everything outside of human experience, particularly religion and myth, as metaphysical, whereas Heidegger argues the matter in terms of the meaning of Being. He also describes metaphysics as a mode of thinking that treats Being only by reducing it to being, and he considers the Enlightenment to be a continuation of this metaphysical tradition.

13 Immanuel Kant, "An Answer to the Question: What is Enlightenment?" in Lawrence E. Cahoone (ed.), From Modernism to Postmodernism: An Anthology (Maiden, Mass.: Blackwell Publishers, 1996), 51.

14 Hans Bertens, The Idea of the Postmodern: A History (London \& New York: Routledge, 1995), 166.

** Here, it is crucially important to address the concept of time conception in metaphysical thought. The creation of a calculable world within an eternal present has become possible through the mathematical conception of time. This approach transforms it so that the truth becomes an object which is outside us staying-there and which can be obtained through the usage of necessary epistemological instruments. 
epistemological methods in such a manner that the Being of the thing, which is made the object of reflection, is forgotten. Along with this argument, Heidegger underlines that the dominant way of thinking in Western metaphysics is not the type of meditative thinking that is found in the pre-Socratic Being experience. Western metaphysics allows the true thing to be reflected upon to remain unthought, and it realizes its reflection is pursuant to human interests since it contains humanistic content. Accordingly, calculative thinking can be considered an activity of computing based on interests rather than on meaning:

Calculative thinking computes. It computes ever new, ever more promising and at the same time more economical possibilities. Calculative thinking races from one prospect to the next. Calculative thinking never stops, never collects itself. Calculative thinking is not meditative thinking, not thinking which contemplates the meaning which reigns in everything that is. ${ }^{15}$

Calculative thinking - which became prevalent in the scientific manner of thought, as is reflected in modern technology - considers the world to be a source standing out there. In the modern period, referred to as Gestell (framing) by Heidegger, Being is seen only as a source that stands for industry and technology.

And yet the revealing that holds sway throughout modern technology does not unfold into a bringing-forth in the sense of poiesis. The revealing that rules in modern technology is a challenging, which puts to nature the unreasonable demand that it supply energy that can be extracted and stored as such. ${ }^{16}$

Just as a windmill surrenders to a blowing wind, the modern technique concentrates on storing and locking up energy in an entirely unnatural way. ${ }^{17}$ Similarly, Heidegger uses the hydroelectric power

15 Heidegger, Discourse on Thinking (trans. John M. Anderson and E. Hans Freund; New York: Harper \& Row Publishers, 1966), 46.

16 Heidegger, "The Question Concerning Technology," in his The Question Concerning Technology and Other Essays (trans. William Lovitt; New York: Garland Publishing, 1977), 14.

17 Heidegger, Tekniğe Ilişkin Soruşturma [The Question Concerning Technology] (translated into Turkish by Doğan Özlem; Istanbul: Paradigma Yayınları, 1998), 55. 
plant built on the Rhine as an example. ${ }^{18}$ Modern science, dominated by calculative thinking, entraps and securely refines the real by means of theory as observation. Therefore, according to Heidegger, "modern science as theory in the sense of an observing that strives after is a refining of the real that does encroach uncannily upon it." 19

For Heidegger, modern science, which intends to control "the real" and render it predictable by making it an object of calculative thinking rather than steering for its being, should be considered an entrapping representation that corresponds with reality: "Science sets upon the real. It orders it into place to the end that at any given time the real will exhibit itself as an interacting network, i.e. a surveyable series of related causes. The real thus becomes surveyable and capable of being followed out in its sequences. The real becomes secured in its objectness. From this there result spheres or areas of objects that scientific observation can entrap after its fashion." ${ }^{20}$ From this perspective, either everything is objectified in a calculative manner that prioritizes epistemology or it is excluded for being irrational when such objectifying is impossible. Especially with the Cartesian metaphysics of subjectivity, the language leaves itself to our will and control, as an instrument for establishing dominance over beings. Thereupon, the beings themselves begin to be seen as realities that interact with cause and effect. ${ }^{21}$

In the Heideggerian view, even modern scientific concern with control and predictability is similar to metaphysical thought. Therefore, the language of metaphysical thought makes not only Being, but also God, religion and man the object of a calculative logic. Thus, the language does not reflect them either. In fact, regarding the possibilities of the language of religion, criticisms of rational theology are essentially about the fact that religion and God are treated within the scope of logic, which reduces them to rational. Nietzsche considered Pascal to be a Christian of single logic because he said "God of Abra-

\footnotetext{
$18 \quad$ Ibid., 57.

19 Heidegger, "Bilim ve Düşünüm," 27; cf. id., "Science and Reflection," in The Question Concerning Technology and Other Essays, 166-167.

20 Heidegger, "Bilim ve Düşünüm," 28; cf. id., "Science and Reflection," 167-168.

21 Heidegger, “Hümanizm' Üzerine Mektup,” in Ahmet Aydoğan (ed. and trans.), Hümanizmin Özü: Heidegger, Sartre, Eliot, Babbit (Istanbul: İz Yayınc1lık, 2002), 43-44.
} 
ham, God of Isaac, God of Jacob, not of the philosophers and the scholars," which means that man is not only a being of reason, but also one with feelings and instincts, and religion and God resists being reduced to the rational level ${ }^{22}$ in his onto-theological criticisms. Similarly, Heidegger is a significant inspiration for criticisms of rational theology, even though his philosophy is not assigned to religion and God. This is why Heideggerian onto-theological criticism is relevant to our study, particularly in comprehending the content of socalled religious thought.

\section{The Relationship between Logic, Metaphysics and Onto- theo-logy}

Heidegger's criticisms of onto-theology is important to the way thought, particularly religious thought, has been understood throughout the history of metaphysics, and to the kind of a metamorphosis it underwent. This process of metamorphosis that Heiddegger called the "onto-theo-logical construction of metaphysics" in fact means the subjection of the object of reflection to a humanistic reduction that is related to a rational epistemology by means of fortification of an epistemological way of thinking rather than an ontological one. In other words, the way of thinking that has claimed to attain this essence throughout the history of metaphysics has chosen to fictionalize the object of reflection rather than reflecting on it. That is why this tradition has become alienated from both reflection and the meaning of Being. The metaphysical manner of thinking, which Heidegger criticizes as onto-theology, is nothing but this fiction realized, based on a way of thinking that prioritizes epistemology. A healthier assessment of how this fiction came to be can be possibly pursuant to the following evaluations by Heidegger on metaphysics:

Metaphysics thinks of beings as such, that is, in general. Metaphysics thinks of beings as such, as a whole. Metaphysics thinks of the Being of beings both in the ground-giving unity of what is most general, what is indifferently valid everywhere, and also in the unity of the all that accounts for the ground, that is, of the All-Highest. The Being of beings is thus thought of in advance as the grounding ground. Therefore, all metaphysics is at bottom, and from the ground up, what

22 Hans Küng, Does God Exist? An Answer for Today (trans. Edward Quinn; Garden City, NY: Doubleday, 1980), 382. 
grounds, what gives account of the ground, what is called to account

by the ground, and finally what calls the ground to account. ${ }^{23}$

Heidegger carries out these analyses on the content of metaphysics in order to experience the concepts of ontology, theology and onto-theology through their own centers of gravity. As a matter of fact, the suffix 'logy' (logos) refers to an entire relation of foundation according to which the objects of sciences are designed and therefore comprehended.

Ontology, however, and theology are "Logies" inasmuch as they provide a foundation for beings and account for them within the whole. They account for Being as the ground of beings. They account for the Logos and are in an essential sense in accord with the Logos-, that is they are the logic of the Logos. ${ }^{24}$

This is why, for Heidegger, their common name should be ontotheo-logic. From this point of view, logic "is the name of thinking that gets to the root of being as such in the sense of being as logos in everywhere and that grounds it." 25 And when the being of being is designed as the cause of itself, one arrives at the concept of God in metaphysics. ${ }^{26}$

This is why Heidegger calls this tradition of thinking onto-theology. For him,

Metaphysics is ontology in that it thinks of Being as the first and most universal ground common to all beings. Metaphysics is a kind of theology because it thinks of Being as the highest ground above all beings, ultimately as the ground of itself, causa sui, which is the metaphysical concept of God. Metaphysics is thus in its very nature ontotheo-logic. ${ }^{27}$

23 Heidegger, Özdeşlik ve Ayrm (translated into Turkish by Necati Aça; Ankara: Bilim ve Sanat Yayınlar1, 1997), 42; cf. id., Identity and Difference (translated with an introduction by Joan Stambaugh; New York: Harper \& Row Publishers, 1969), 58.

Heidegger, Identity and Difference, 59. Heidegger, Özdeşlik ve Ayrm, 43; cf. id., Identity and Difference, 59. Heidegger, Özdeşlik ve Ayrm, 44; cf. id., Identity and Difference, 60.

27 Heidegger, "Metafiziğin Onto-teo-lojik İnşası [The Onto-theo-logical Constitution of Metaphysics]," in Ahmet Demirhan (ed. and trans. into Turkish), Heidegger ve 
In other words, the onto-theological quality of metaphysics arises from the very nature of metaphysics, and since the comprehension of beings (logos) leads to asking questions about the origin of Being, and this origin is called God (Theos), it is possible to claim that according to Heidegger, every philosophy is also a theology. ${ }^{28}$

When considered within the context of these assessments, since the Western tradition of metaphysics treats Being reduced to a being in terms of its essence and characteristics, it is an ontology (Onto: Being), and as it treats Being in terms of source and ground for beings as the highest and most principal selfdom, it is an onto-theo-logy (Theo: God). Accordingly, for Heidegger, throughout the tradition of metaphysical thinking, the effort to understand the transcendent ground of all beings in terms of a transcendent Being has brought along hazardous effects in both philosophy (thinking) and theology (religious thought). This onto-theological approach constrains philosophy from considering Being as a non-being, whereas it hinders the true relation with the divine by misinterpreting the nature of God. ${ }^{29}$ In fact, because theology accepts God as an exterior source in the chain of creation, Heidegger contends that it reduces the divine or the true God to the God of philosophers, and this reveals the ontotheological approach in the very essence of the entire Western metaphysics tradition. In Heidegger's opinion, this tradition of metaphysics establishes our fundamental and final conceptual parameters by ontologically grounding and theologically legitimizing our historical comprehension of 'what is. ${ }^{30}$ As Wayne Hankey points out, considering theological history in terms of onto-theo-logy will reveal that God has been considered a being encircled by horizons given through a chain of the notions of being. Such a confinement is not only in question for God, but also for man. In this respect, one can even claim

Teoloji [Heidegger and Theology] (Istanbul: İnsan Yayınlar1, 2002), 65; Joan Stambaugh, "Introduction," in Identity and Difference, 15.

28 John Reynold Williams, Heidegger'in Din Felsefesi [Martin Heidegger's Philosophy of Religion] (translated into Turkish by Mehmet Türkeri; Izmir: İzmir İlahiyat Vakfı Yayinları, 2005), 124.

29 Mark A. Wrathall, "Introduction: Metaphysics and Onto-Theology," in Mark A. Wrathall (ed.), Religion After Metaphysics (Cambridge: Cambridge University Press, 2003), 2.

30 Iain D. Thomson, Heidegger on Ontotheology: Technology and the Politics of Education (Cambridge: Cambridge University Press, 2005), 2. 
that in the Western tradition of metaphysics, the relationship man has with himself and the world is formed within certain theologies that are determined ontologically. ${ }^{31}$

This very process of formation reveals the epistemologically ${ }^{*}$ privileged character of philosophy and thus of metaphysics. Because epistemology searches for the nature of the knowledge behind things, the question is always, "what is this?" Responses to this question also assume a representative relationship between the interrogative and the defined. For example, when we ask "What is man?," we choose to define man in terms of what makes him what he is, namely, his essence, and we also reduce man to a definition that excludes all situations except for the form by means of determining man in a form that cannot be otherwise. This philosophical approach, which Levinas called ontological imperialism, singles out a dominant way of thinking that obstructs, excludes or agrees with the prescribed epistemic context of many things in general about Being, and specifically in the current example, man. Yet, to define a thing by its characteristics implies an inherent assertion about how it should be. This, in a sense, is similar to the way the dog in a picture does not bark or Foucault's famous "this is not a pipe" premise signifies how epistemological fictions based on a representative relationship are detached from existence.

According to Heidegger, and in keeping with a way of thinking that is primarily based on epistemology, the method of metaphysics

31 Wayne Hankey, "Theoria versus Poesis: Neoplatonism and Trinitarian Difference in Aquinas, John Milbank, Jean-Luc Marion and John Zizioulas," Modern Theology 15/4 (1999), 387.

* Even though the most absolute form of an epistemological way of thinking consists of a modern-age epistemology that "searches for possibility and limits of knowledge, determines the content of knowledge and then advances to analyze our faith, values, judgments and views in consideration of such determination" (Doğan Özlem, Kültür Bilimleri ve Kültür Felsefesi [The Sciences of Culture and Philosophy of Culture] [Istanbul: Remzi Kitabevi, 1986], 68), as Heidegger emphasizes, the dominant philosophical way of thinking in Western metaphysics can be described as an entirely theoretical activity of thinking that is primarily based on epistemology, which prefers to comprehend Being in terms of the abovementioned theoretical activity, apart from ignoring historicity, existence and life within the scope of the contrast between theory and history. 
that reduces Being to a being and entraps everything into certain categories with respect to ontology signifies an unawareness of the most crucial question about the meaning of Being for man. Ontological categories developed under this tradition are seen as manifest, and they are perceived as the eternal and effective salvation of the intellect. However, Heidegger thinks that philosophical categories, which he considers to be apparently obvious, possess historical contingence. $^{32}$ That is, ontological categories designed by attributing them to absoluteness, ahistoricity and universality are in fact historically constructed within the humanistic approach, rather than an ontological reflection, and they are epistemological categories that claim to theorize or represent the truth.

Through a Heideggerian perspective, the main problem within the content of the humanistic approach that claims to theorize or represent the truth is that it is not open to the meaning of the thing that it turns into an object of reflection. As a matter of fact, the most important prerequisite for thinking about the meaning of Being in general and of any being in particular is to be ontologically open to the being of the reflected thing. However, due to the abovementioned epistemology-based attitude of humanistic thinking, it is out of the question to move beyond the construction of meaning. In our opinion, the most apparent example of this problem can be seen in metaphysical attitudes regarding the relationship man establishes with God.

\section{Metaphysical Thought and Religion}

Based on the continuity of Western metaphysics, Heidegger emphasizes that metaphysics established its most concrete form via modern technology, and the control and dominance of reality eventually transformed into a dominance that also included man. Modern man, as Nietzsche stresses, lives in an age of nihilism, where the high values, the ideas of substance and finally onto-theological comprehensions of God established by the metaphysical tradition, trivialize themselves over the course of time under the dominance of a scientific worldview. Even worse, the madman of Nietzsche is aware of the greatness of the absence of God, whereas modern man, called 'last

32 Stephen Mulhall, Heidegger ve Varlık ve Zaman [Heidegger and Being and Time] (translated into Turkish by Kaan Ökten; Istanbul: Sarmal Yayınevi, 1998), 39. 
man' by Nietzsche and 'das-Man', namely, the They by Heidegger, is even unaware of the situation. Moreover, according to Heidegger, people in the marketplace who make fun of Nietzsche's madman have lost their faith in God not because they think God is not worthy of belief, but because they have abandoned the possibility of believing. "Because," says Heidegger, "they are incompetent in reflection, they have left reflecting and instead, have filled the marketplace with empty talk." 33

This evidently does not signify a desire by Heidegger for reanimating the metaphysical imaginings of God. Modern man has to live in a godless world following the collapse of the onto-theo-logical imaginings of God. Nevertheless, Heidegger claims that man bears the possibility of being closer to the divine God, even if he gives up empty talking and lends an ear to the voice of Being. "Causa sui," adds Heidegger, "This is the proper name for God in [metaphysics] philosophy. To this God man can neither pray nor offer sacrifice. Before the causa sui man can neither fall to his knees in awe nor can he play music and dance before this god... Therefore, thinking which must abandon the God of philosophy, God causa sui, is perhaps closer to the divine God." In other words, the god-less thinking "is freer for Him than onto-theo-logy would like to admit." ${ }^{34}$ Evidently, however, such a reflection cannot be realized by man, who, according to Heidegger, forgets that even the question of the meaning of Being is forgotten, or as Nietzsche's last man, does nothing but pursue his own desires.

It is possible to affirm that with capitalist lifestyles and consumer culture, man lives a life that adheres to Nietzsche and Heidegger's descriptions of modern man. Modern man, who worries about nothing but the pursuit of human desires, enjoying a more comfortable life and continuously consuming without making any distinctions among his desires regarding value or quality, is clearly incompetent when it comes to reflection and comprehension. Modern life is full of such thoughtlessness and lack of meaning. For example, in terms of modern intellectual culture, the parallelisms established almost reluctantly between religion and science via interpretations of religion

33 John Peacocke, "Heidegger ve Onto-teoloji Sorunu [Heidegger and the Problem of Onto-theology]," in Heidegger ve Teoloji, 165.

34 Heidegger, "Metafiziğin Onto-teo-lojik İnşası," 66; id., Identity and Difference, 72. 
from a modernist perspective put religious texts and traditional religious lifestyles to a historical reading which will eventually make them compatible with the modern world. Their concern about maintaining the harmony of modern lifestyles constitutes only a few examples of the epistemological perspective that is essentially detached from any religious thought. Again, many people in the modern world who consider themselves connected to a certain religion are nonetheless within a consumption logic that snubs the relationship styles and moral hierarchies prescribed by their religion regarding God, man and the universe. Evidently, this is a consequence of the abovementioned incompetence when it comes to reflection. ${ }^{*}$ Such inaptitude arises from the fact that the world in which modern man lives is essentially constructed with a humanistic logic, and both God and religion participate in this process of construction.

Both God and religion serve important functions in the eyes of modern man..$^{35}$ It is impossible to talk about God and religion having any sanctioning power on man, except for meeting his psychological needs. It should be noted that in the modern world, the phenomenon of returning to religion and the divine is entirely deceptive. Religious thinking pays attention to man's ontological connection with God, whereas man in the modern world has a more logical relationship with God, whom he makes an object of imagination that exists only to fulfill his religious need, or whom he seeks out from a sense of abandonment. It is evidently doubtful that a God who has no choice but to forgive and is pacified by the human imagination is really a

* Numerous examples can be given in this respect. Since the desires of modern people of faith are, just like those of other men within consumer culture, encoded towards capitalist consumer products, the modern faithful man takes comfort in either integrating into such life practice without giving importance to values of religion he belongs to, or through a relief that arises via reconciliation of his own values with modern values. The phenomena of such fashion shows, resorts for the faithful, the efforts for a more luxurious and comfortable life, indifference to famine, poverty and ecological balance are typical features that demonstrate how, in fact, religious thought and practices arising from such thinking are unimportant in the eyes of modern man.

35 Regarding reduction of religion to a functional and instrumental function in terms of moral and social control, see İbrahim Kalın, "Dinî ve Bilimsel Enstrümentalizm: Çıkmazlar, Çözüm Arayışları [Religious and Scientific Instrumentalism: Deadlocks, Seeking Solutions]," Dîvân 1/1 (1996), 107-118. 
God. Humanist theologians especially encourage modern man to transform his conception of God, who is traditionally an object of fear, in favor of viewing God as an object of love. In other words, they convince man that God does not contact him from some unknown world, and man's ability to reach this other world does not depend on his deeds in this world. Afraid of man's potential for evil, such a tame God is a flexible being that is adaptable to human psychology. It is possible to avoid making God an object of design, I reckon, through establishing an understanding that arises from a determination of being in the true sense by resolutely responding to rooted questions about the meaning of existence.

\section{Instead of a Conclusion: Pure or Meditative Thinking (Reli- gious Thinking) as a Possibility of a Non-Metaphysical Reli- gious Thought}

Heidegger defines meditative thinking as non-calculative thinking that is determined through the otherness of Being and considers the ontological difference between Being and beings. The basic characteristic of this mode of thought is that the being sacrifices itself within Being for the sake of the truth of Being. ${ }^{36}$ Such a thought does not impose a fictional perspective onto things, but rather it accepts them as they are and respectfully lets them exist in silence. Therefore, reflection refers to an unconstrained and altruistic (or non-selfish) activity. Moreover, such reflection is pious, accepting and respectful. It "is a truly accepting response to the call or voice of Being. ${ }^{37}$ In this context, comprehension is not a theoretical or epistemological activity. Instead, its content is entirely related to practice, and it corresponds to the active part of the encounter between man and his own existential-Being possibilities. ${ }^{38}$

Heideggerian meditative thinking contends that auditory metaphors are more important than visual ones, and it views Speech as the essence of language. The privilege given to sound enables an explanation of the etymological affinity between the words "to hear" (bören), "to be all ears" (horchen), "to belong" (gehören) and finally "to obey" (gehorchen) in German. Therefore, "to hear" refers to "to be

\footnotetext{
36 Heidegger, Metafizik Nedir?, 49.

37 Peacocke, "Heidegger ve Onto-teoloji Sorunu," 160.

38 Mulhall, Heidegger ve Varlık ve Zaman, 116-117.
} 
all ears," "to belong" and "to obey." In the same context, a thought that hears the call of Being is one that expresses gratitude for being the object of such a call and therefore becomes obedient to it. A pious hearer who participates in the call abandons the request to tyrannize the true nature of beings by means of the narcissistic approach of the visual. ${ }^{39}$ Without a doubt, leaving beings as they are necessitates freeing them from ontological categories that are built via the epistemological character of metaphysical tradition, as well as considering man not as a being of intellect, but as a Being that humbly consents to its fate and enters into an existential relationship with Being and beings, rather than a theoretical-fictional relationship.

This is why Heidegger thinks that the realization of meditative thinking can be possible only through comprehending that the intellect, which has reigned for centuries, is the most "stiff-necked adversary of thought.." ${ }^{\prime 0}$ For this manner of thought, reality, Being and truth are all understood through actively participating in temporality and existence, which are the meaning of Being and can be comprehended by surrendering, instead of entering into an ahistorical realm of being that remains outside of us and can be theorized through various epistemological methods. At this point, Heidegger uses an etymological analysis to explain the true meaning of reflection. In German, the words sinnan and sinen (to sense) mean "to follow a direction that is the way that something has, of itself, already taken." The source of Besinnen (reflecting), which is derived from the same stem, is "to venture courageously after sense or meaning (Sinn)." Therefore, it involves more than simply comprehension. Consequently, "we do not yet have reflection when we have only consciousness. Reflection is more. It is a calm, self-possessed surrender to that which is worthy of questioning." 11 Therefore, reflection in the Heideggerian view possesses an essence that is different from consciousness, scientific knowledge, and the intellectual cultivation that is unarguably essential to a modern lifestyle.

39 Peacocke, "Heidegger ve Onto-teoloji Sorunu," 160-161.

40 Heidegger, "The Word of Nietzsche 'God Is Dead'," in The Question Concerning Technology and Other Essays, 112; cf. id., "Nietzsche'nin 'Tanr1 Öldü' Sözü,” in his Nietzsche'nin 'Tanr Öldü' Sözü ve Dünya Resimleri Çağı (translated into Turkish by Levent Özşar; Bursa: Asa Kitabevi, 2001), 61.

41 Heidegger, "Science and Reflection," 180. 
Heidegger's criticisms of intellectual cultivation are especially remarkable in this respect.

Intellectual cultivation brings before man a model in the light of which he shapes and improves all that he does. Cultivating the intellect requires a guiding image rendered secure in advance, as well as a standing-ground fortified on all sides. The putting forward of a common ideal of culture and the rule of that ideal presupposes a situation and bearing of man that is not in question and that is secured in every direction. This presupposition, for its part, must be based on a belief in the invincible power of an immutable reason and its principles. ${ }^{42}$

On the other hand, reflection, which is a historical dwelling, incorporates us into our dwelling for the first time. This is why reflection is more cautious, provident and poor compared to intellectual cultivation. As a matter of fact, "the ways of reflection constantly change, ever according to the place on the way at which a path begins, ever according to the portion of the way that it traverses, ever according to the distant view that opens along the way into that which is worthy of questioning." ${ }^{43}$ Obviously, the possibility for true reflection requires giving up the search for rational knowledge in modern thinking and philosophy. Relieving the problem from being methodical allows man to escape from the theoretical and fictional objections that he puts between truth and his own Being and which obstruct him from contemplating the truth. In doing so, he assumes responsibility for his own existence.

Indeed, Heidegger identifies meditative thinking as a nonmetaphysical way of thinking on the one hand, and on the other hand, when considered along with onto-theology criticisms, a nonmetaphysical religious thought. First of all, as with the Heideggerian view, religious thought, which prioritizes ontology, maintains an ontological openness towards the Being that is made the object of reflection. In religious thought that is interpretative rather than explanatory, man is invited to find the answers to certain fundamental questions about the meaning of an entire realm of Being in general and his own existence in particular. This reigning interpretative logic operates so that the person who accepts the invitation opens himself to truths that he personally finds in the midst of questions and which

\footnotetext{
42 Heidegger, "Bilim ve Düşünüm,” 42; cf. id., "Science and Reflection," 180.

43 Heidegger, "Bilim ve Düşünüm,” 43; cf. id., "Science and Reflection," 181.
} 
give meaning to existence by means of abandoning his search for explanatory responses. As a result, an entire realm of Being attains the possibility of being experienced within its ontological connection with God.

As for thinking about man and other Beings in terms of their ontological connections with God, this presupposes escaping from the theoretical (humanistic) obstacles placed by man between himself and truth. Thus, man is no longer an obstacle to that which he has made an object of reflection, and he begins to contemplate the ontological connection that all Beings have with God by letting things be. Levinas, who was deeply influenced by Heideggerian philosophy, associates the face of the other with the trace of God. ${ }^{44}$ In religious thought, man is invited to see the divine trace carried by an entire realm of being and to realize all his relationships with beings in light of this. Religious thought does not choose to design either God or man, or even other created Beings by means of making them objects of knowledge belonging to a thought that prioritizes epistemology. The point here is to get out of the way of Being, which is made the object of reflection, and allow it to reveal itself to us as it is. This question, corresponding with the Heideggerian concept of letting be and releasement ${ }^{45}$ is actualized in religious thought through concepts such as fate, consent and faith.

Consequently, when it comes to religious thought, it is impossible for man to test God, man or the world in which he is created as an object of imagination. As referred to above in saying, "from God shaped by imagination, to God who shapes imagination," a man who adheres to religious thought does not have a rational foundation of thought, and he does not strive to reduce his knowledge about God, religion, man and Being to the limits of human rationality. Here, man realizes his reflection via existence, and he also contemplates the truths that God reveals to him by means of existence. The pious man knows he will be entrapped within the limitations of the human intellect, and he will reduce everything to this intellect if there is no exist-

44 For association established by Levinas' philosophy between God and the other, see Jeffrey Bloechl (ed.), The Face of the Other and the Trace of God: Essays on the Philosophy of Emmanuel Levinas (New York: Fordham University Press, 2000).

45 For a more detailed analysis on these concepts, see Michael Inwood, A Heidegger Dictionary (Maiden, Mass.: Blackwell Publishers, 1999), 116-118. 
ence. Accordingly, he knows that the possibility of attaining the truth depends on obedience and surrender. That same way that Heidegger describes man as "being-towards-death," in religious thought, man is first invited to understand his own mortality. In such a mode of thought in which Being is almost synonymous with nothing, man transitions from the illusory to true existence. Continuously underlining the mortality and limitedness of man, this invitation invokes the fact that man possesses nothing, and God controls everything. Therefore, man makes a vital preference between an illusory existence based on the idea of property and a true existence that can be attained only by abandoning the concept of property. Indeed, the beginning point of the way of thinking we call religious thought corresponds exactly to this very moment of choice.

\section{REFERENCES}

Bertens, Hans, The Idea of the Postmodern: A History (London \& New York: Routledge, 1995).

Bloechl, Jeffrey (ed.), The Face of the Other and the Trace of God: Essays on the Philosophy of Emmanuel Levinas (New York: Fordham University Press, 2000).

Hankey, Wayne, "Theoria versus Poesis: Neoplatonism and Trinitarian Difference in Aquinas, John Milbank, Jean-Luc Marion and John Zizioulas," Modern Theology 15/4 (1999), 387-415.

Heidegger, Martin, Discourse on Thinking (trans. John M. Anderson and E. Hans Freund; New York: Harper \& Row Publishers, 1966).

Identity and Difference (translated with an introduction by Joan Stambaugh, New York: Harper \& Row Publishers, 1969); Turkish translation: Özdeşlik ve Ayrm (translated into Turkish by Necati Aça; Ankara: Bilim ve Sanat Yayınları, 1997).

"Letter on Humanism" (trans. Frank A. Capuzzi), in his Pathmarks (ed. William McNeill; Cambridge: Cambridge University Press, 1998); Turkish translation: "Hümanizm' Üzerine Mektup," in Ahmet Aydoğan (ed. and trans.), Hümanizmin Özü: Heidegger, Sartre, Eliot, Babbit (Istanbul: İz Yayınc1lık, 2002), 37-95.

"Metafiziğin Onto-teo-lojik İnşası [The Onto-theo-logical Constitution of Metaphysics]," in Ahmet Demirhan (ed. and trans. into Turkish), Heidegger ve Teoloji [Heidegger and Theology] (Istanbul: İnsan Yayinlar1, 2002), 49-71. 
"Science and Reflection," in his The Question Concerning Technology and Other Essays (trans. William Lovitt; New York: Garland Publishing, 1977), 155-182; Turkish translation: "Bilim ve Düşünüm," in his Bilim Üzerine İki Ders [Two Essays by Heidegger on Science] (translated into Turkish by Hakkı Hünler; Istanbul: Paradigma Yayinlar1, 1998), 13-44.

"The Question Concerning Technology," in his The Question Concerning Technology and Other Essays (trans. William Lovitt; New York: Garland Publishing, 1977), 3-35; Turkish translation: Tekniğe İlşkin Soruşturma (translated into Turkish by Doğan Özlem; Istanbul: Paradigma Yayınları, 1998).

"The Word of Nietzsche 'God Is Dead'," in his The Question Concerning Technology and Other Essays (trans. William Lovitt; New York: Garland Publishing, 1977), 53-112; Turkish translation: "Nietzsche'nin 'Tanr1 Öldü' Sözü," in his Nietzsche'nin 'Tanr Öldü' Sözü ve Dünya Resimleri Çağı (translated into Turkish by Levent Özşar; Bursa: Asa Kitabevi, 2001), 11-63.

"What is Metaphysics?" (trans. David Farrell Krell), in his Pathmarks (ed. William McNeill; Cambridge: Cambridge University Press, 1998), 82-96; Turkish translation: Metafizik Nedir? (translated into Turkish by Yusuf Örnek; Ankara: Türkiye Felsefe Kurumu, 1991).

What is Philosophy? (translated with an introduction by William Kluback and Jean T. Wilde; Albany: New College and University Press, 1956); Turkish translation: Nedir Bu Felsefe? (translated into Turkish by Dürrin Tunç; Istanbul: Logos Yayınc1lık, 1990).

Inwood, Michael, A Heidegger Dictionary (Maiden, Mass.: Blackwell Publishers, 1999).

Kalın, İbrahim, "Dinî ve Bilimsel Enstrümentalizm: Çıkmazlar, Çözüm Arayışları [Religious and Scientific Instrumentalism: Deadlocks, Seeking Solutions]," Dîvân 1/1 (1996), 107-118.

Kant, Immanuel, "An Answer to the Question: What is Enlightenment?" in Lawrence E. Cahoone (ed.), From Modernism to Postmodernism: An Anthology (Maiden, Mass.: Blackwell Publishers, 1996), 51-57.

Küng, Hans, Does God Exist? An Answer for Today (trans. Edward Quinn; Garden City, NY: Doubleday, 1980).

Mulhall, Stephen, Heidegger ve Varlik ve Zaman [Heidegger and Being and Time] (translated into Turkish by Kaan Ökten; Istanbul: Sarmal Yayinevi, 1998). 
Özlem, Doğan, Kültür Bilimleri ve Kültür Felsefesi [The Sciences of Culture and Philosophy of Culture] (Istanbul: Remzi Kitabevi, 1986).

Peacocke, John, "Heidegger ve Onto-teoloji Sorunu [Heidegger and the Problem of Onto-theology]," in Ahmet Demirhan (ed. and trans. into Turkish), Heidegger ve Teoloji [Heidegger and Theology] (Istanbul: İnsan Yayınları, 2002), 147-168.

Sallis, John, "Heidegger/Derrida and Presence," The Journal of Philosophy 81/10 (1984: Eighty-First Annual Meeting American Philosophical Association, Eastern Division), 594-601.

Stambaugh, Joan, "Introduction," in Heidegger, Identity and Difference (translated with an introduction by Joan Stambaugh; New York: Harper \& Row Publishers, 1969), 7-18.

Thomson, Iain D., Heidegger on Ontotheology: Technology and the Politics of Education (Cambridge: Cambridge University Press, 2005).

Vattimo, Gianni, Modernliğin Sonu: Postmodern Kültürde Nibilizm ve Hermenötik [The End of Modernity: Nibilism and Hermeneutics in Postmodern Culture] (translated into Turkish by Şehabettin Yalçın; Istanbul: İz Yayınc1lk, 1999).

Williams, John Reynold, Heidegger'in Din Felsefesi [Martin Heidegger's Philosophy of Religion] (translated into Turkish by Mehmet Türkeri; Izmir: İzmir İlahiyat Vakf1 Yayınları, 2005).

Wrathall, Mark A., "Introduction: Metaphysics and Onto-Theology," in Mark A. Wrathall (ed.), Religion After Metaphysics (Cambridge: Cambridge University Press, 2003), 1-6. 